\title{
Robust
}

\author{
Research Business and Economics Studies
}

journal homepage: http://ejournal.iainkendari.ac.id/robust

\section{Strategi Marketing Usaha Pemancingan Pada Masa Pandemi Covid-19 di Desa Kalijambe}

Kidul, Sragi, Pekalongan

Nina Yuliantika ${ }^{1}$, Hendri Hermawan Adinugraha ${ }^{2}$

${ }^{1,2}$ IAIN Pekalongan

e-mail: ${ }^{1}$ ninayuliantika27@gmail.com, ${ }^{2}$ hendri.hermawan@iainpekalongan.ac.id

\begin{tabular}{|c|c|}
\hline ARTICLE INFO & A B S T R A C T \\
\hline Keywords: & Coronaviruses merupakan virus yang menginfeksi saluran \\
\hline \multirow[t]{5}{*}{ Bisnis, Pemancingan, dan Covid-19. } & pernafasan. Infeksi dari virus ini disebut dengan covid-19. \\
\hline & Penyebaran virus ini sangat pesat sehingga sektor ekonomi \\
\hline & mengalami keguncangan. Dengan adanya pembatasan sosial \\
\hline & berskala besar mengakibatkan UMKM mengalami \\
\hline & penurunan omset yang sangat drastis. Mulai dari bisnis \\
\hline Article History: & fashion, elektronik, peralatan rumah tangga, taman bermain \\
\hline Received 02 January 2021 & anak-anak, hingga bisnis pemancingan. Tujuan penelitian \\
\hline $1^{\text {st }}$ Received in revised form 11 February & ini yaitu : (1) Mengetahui bagaimana kondisi bisnis \\
\hline 2021 & pemancingan di era pendemi covid-19 (2) Mengapa banyak \\
\hline $2^{\text {nd }}$ Received in revised form 21 March & konsumen yang berkunjung di Usaha Pemancingan (3) \\
\hline 2021 & Profitabilitas bisnis Usaha pemancingan per bulan tahun \\
\hline $3^{\text {rd }}$ Received in revised form 12 April & 2020. Jenis penelitian ini adalah penelitian lapangan (field \\
\hline 2021 & research) dengan menggunakan pendekatan deskriptif \\
\hline \multirow[t]{8}{*}{ Available online 30 April 2020} & kualitatif. Hasil penelitian, Usaha pemancingan mengalami \\
\hline & kerugian material yang cukup besar akibat pandemi ini. \\
\hline & Namun berbeda dengan Usaha pemancingan yang justru \\
\hline & mengalami peningkatan omset pada era pandemi covid-19. \\
\hline & Banyak konsumen usaha pemancingan yang berkunjung \\
\hline & dikarenakan beberapa hal yaitu: lokasi yang strategis, harga \\
\hline & murah, mengurangi rasa bosan, lokasi dekat, diberhentikan \\
\hline & kerja, dan mengurangi penggunaan gadget. Omset yang \\
\hline http://dx.doi.org/ & dihasilkan oleh Usaha pemancingan pada bulan juni 2020 \\
\hline (C) $2021 \mathrm{Li}$ Falah. All rights & yaitu sebesar Rp. 37.325 .000 dengan total keuntungan \\
\hline reserved & sebesar Rp. 17.600.000. \\
\hline
\end{tabular}




\section{Pendahuluan}

Menurut (Silpa Hanoatubun, 2020) Coronaviruses merupakan virus yang menginfeksi saluran pernafasan. Infeksi virus ini disebut dengan Covid-19. Serangan dari virus ini dapat mengakibatkan sakit flu, demam, sindrom pernapasan timur tengah (MERS-CoV), bahkan sindrom pernapasan akut parah (SARSCoV). Dari serangan virus tersebut, tidak sedikit orang yang meninggal disebabkan covid-19.

Kompas.com melansir data dari laman Worldometers, senin 06 Juli 2020, tercatat 11.544 .660 (11.5 juta) kasus virus corona yang telah terjadi diseluruh dunia. Jumlah kematian akibat virus corona yaitu 536.346 orang di seluruh dunia. Sementara jumlah pasien yang sembuh dari penyakit ini yaitu 6.526.749 (6.5 Juta) orang diseluruh dunia. Adapun kasus aktif hingga kini berjumlah 4.481.565 (4.4 juta) kasus.

Pemerintah Indonesia mengumumkan jumlah penambahan kasus baru virus corona sebanyak 1.607 sehingga total kasus di Indonesia menjadi 63.749. Jumlah korban yang meninggal dunia disebabkan virus covid-19 sebanyak 3.171 orang di Indonesia. Sedangkan jumlah pasien yang sembuh dari penyakit ini sebanyak 29.105 orang.

Penyebaran virus covid-19 yang sangat pesat mengakibatkan sektor ekonomi mengalami keguncangan. (Budastra, 2002) mengungkapkan bahwa mulai dari sektor pariwisata, jasa transportasi, industri pengolahan, sektor perdagangan, dan jasa lainnya sudah mengalami keguncangan. Dimana sektorsektor tersebut merupakan penopang dari penerimaan pajak di Indonesia. Gangguan yang ditimbulkan yaitu rantai pasok input, operasi produksi, rantai distribusi, dan pemasaran yang berakibat dampak negatif pada sektor ekonomi.

Menurut Thaha (2020) Usaha Kecil dan Menengah menduduki baris pertama yang mendapatkan guncangan ekonomi akibat pandemi covid-19. Dengan adanya sistem lockdown yang ditetapkan oleh pemerintah Indonesia mengharuskan masyarakat untuk meminimalisir kontak fisik. Hal tersebut mengakibatkan penurunan permintaan konsumen UMKM. Lebih dari 50\% UMKM Indonesia memprediksi bahwa mereka dapat gulung tikar dalam beberapa bulan kedepan karena kebangkrutan terjadi dimana-mana.

Menurut data AC Nielsen dalam ekbis.sindonews.com mengutarakan bahwa ada empat industri yang mengalami kenaikan signifikan pada saat pandemi covid-19 yaitu bisnis hand sanitizer yang semula hanya 1\%, dapat meningkat hingga 199\%, sabun cuci tangan mengalami permintaan hingga 285\%, antiseptik cair 233\%, dan tisu basah $151 \%$. Namun ada beberapa industri yang mengalami penurunan signifikan seperti sektor busana turun hingga 3\%, perawatan bayi dan ibu hamil turun hingga 5\%, produk industri turun hingga $15 \%$, automotif turun hingga $31 \%$, dan properti mengalami penurunan drastis hingga 54\%.

Economy.okezone.com mengungkapkan bahwa bisnis kolam pemancingan merupakan suatu bisnis yang sangat prospek dan memiliki potensi keuntungan besar. Bisnis ini tidak akan pernah mati karena orang 
yang hobi mancing akan selalu mencari kolam pemancingan untuk menyalurkan hobinya. Hal ini juga memberikan potensi besar keberhasilan bisnis Usaha pemancingan di era covid-19.

Larangan kontak fisik tentu membuat masyarakat jenuh dengan aktivitas yang hanya dalam lingkup rumah. Hal ini membuat banyak masyarakat memilih untuk menghabiskan waktunya dengan memancing. Di desa kalijambe terdapat tiga lokasi pemancingan yang jaraknya berdekatan. Namun peneliti tertarik untuk melakukan penelitian di Usaha pemancingan karena lokasi pemancingan tersebut selalu ramai pengunjung. Padahal di era pandemi covid-19 banyak Usaha yang mengalami kebangkrutan bahkan gulung tikar namun Usaha pemancingan tersebut selalu didatangi pengunjung sehingga peneliti tertarik untuk melakukan ini. Tujuan penelitian ini yaitu : (1) Bagaimana kondisi bisnis pemancingan di era pendemi covid-19 (2) Mengapa banyak konsumen yang berkunjung di USsaha Pemancingan (3) Profitabilitas bisnis Usaha pemancingan per bulan tahun 2020 .

\section{Metode Penelitian}

Jenis penelitian ini adalah penelitian lapangan (field research) dengan menggunakan pendekatan deskriptif kualitatif. Penelitian ini bertujuan untuk memperoleh informasi data langsung dari lokasi yang berkaitan dengan objek yang akan diteliti. Penelitian dilakukan dengan mengumpulkan, mengkaji, dan mendeskripsikan terjadinya peningkatan konsumen pemancingan di era pandemi covid-19. Penelitian ini dilaksanakan di Usaha pemancingan yang beralamat desa Kalijambe Kidul, Sragi, Pekalongan.

Data yang diperlukan dalam penelitian ini yaitu data primer dan data sekunder. Data primer diperoleh melalui wawancara langsung responden. Responden dalam penelitian ini yaitu pemilik dan pengunjung Usaha pemancingan. Sedangkan data sekunder diperoleh dari literatur dan sumber data yang menunjang dalam penelitian ini.

Metode pengumpulan data adalah suatu teknik atau cara yang dilakukan untuk mengumpulkan data. Teknik pengumpulan data dalam penelitian ini dilakukan dengan observasi dan wawancara. 


\section{Hasil dan Pembahasan}

\section{Kondisi Bisnis Pemancingan di Era Pendemi Covid-19}

Akibat dari adanya penyebaran virus covid-19 memberikan dampak adanya peningkatan minat konsumen untuk memancing. Hal ini dijelaskan oleh Nasuha (32) dalam gatra.com bahwa "kegiatan memancing lebih sering saya lakukan ketika pemerintah menerapkan sistem pembatasan sosial berskala besar (PSBB) sejak april lalu. Dengan memancing dapat mengatasi kebosanan saat dirumah serta dapat menenangkan diri dari keramaian”. Hal ini juga dibuktikan dengan peningkatan jumlah konsumen di Usaha pemancingan. Jumlah pengunjung per harinya sekitar 20 sampai 30 orang dengan jam yang berbeda.

Minat masyarakat untuk memancing tinggi sehingga tak sedikit bisnis pemancingan kerap menjadi sorotan. Namun ada beberapa bisnis pemancingan yang ditutup paksa oleh pihak yang berwajib karena tidak sesuai dengan protokol kesehatan sehingga memungkinkan adanya penyebaran virus covid-19. Salah satu tempat pemancingan yang ditutup yaitu wisata mancing di kecamatan Muaragembong, Kabupaten Bekasi, Jawa Barat (dalam antaranews.com). Pemancingan tersebut ditutup oleh pemerintah setempat dikarenakan untuk mencegah penyebaran covid-19. Pemerintah setempat menghimbau agar masyarakat menunda kegiatan memancing untuk sementara waktu baik bagi pemancing yang berada di sekitar maupun masyarakat yang berasal dari luar Kota.

Namun disamping itu juga banyak tempat pemancingan yang siap dibuka pada era new normal pandemi. Resto dan pemancingan Duren Jati, Desa Darupono, Kecamatan Kaliwungu Selatan, Kendal siap dibuka dengan mematuhi protokol kesehatan yang berlaku (dalam halosemarang.id). Pengunjung wajib mematuhi aturan yang berlaku mulai dari memakai masker, cuci tangan, cek suhu badan, juga tetap menerapkan social distancing yaitu dengan menjaga jarak minimal 1.5 meter antar pengunjung. Usaha resto dan pemancingan ini mengalami kerugian yang sangat besar, apalagi idul fitri merupakan puncak pendapatan Usaha ini dan pada waktu itu belum boleh dibuka. Oleh karena itu untuk menutup berbagai kerugian resto dan pemancingan Duren Jati sudah mempersiapkan diri dan siap dibuka sembari menunggu instruksi dari pemerintah setempat.

\section{Profil Usaha pemancingan, Kalijambe Kidul, Sragi, Pekalongan}

Usaha pemancingan merupakan tempat penyedia lahan pemancingan dimana tiket masuk yang dikenakan yaitu per jam. Tarif yang dipasang Rp.5.000/jam berlaku kelipatan, namun juga terdapat paket hemat sehingga biaya lebih murah untuk memancing lebih lama yaitu seharga Rp. 12.000/ 3 jam. Usaha pemancingan menyediakan alat pancing lengkap tanpa dikenai biaya sewa alat. Usaha ini juga menyediakan umpan (cacing) yang dijual kepada konsumen. Tempat ini juga memiliki satu kantin untuk menunjang 
pemasukan dari Usaha pemancingan karena kantin di kelola oleh pemiliknya langsung. Tak jarang orang yang memancing juga memesan makanan dan minuman untuk menemani kegiatan memancing. Jumlah pengunjung tempat ini didominasi oleh laki-laki dengan total 20 hingga 30 orang perharinya. Hasil tangkapan ikan menjadi hak pemancing karena Usaha pemancingan tidak menerapkan biaya tambahan ketika ikan hasil tangkapan dibawa pulang. Semakin banyak ikan yang diperoleh maka pemancing akan mendapatkan keuntungan dan kebahagiaan tersendiri. Sistem dari Usaha pemancingan yaitu seperti menjual ikan yaitu ikan seharga Rp. 5.000 akan dilepaskan apabila pemancing membeli paket seharga Rp. 5.000. Apabila ikan tidak berhasil ditangkap maka akan menjadi keuntungan Usaha pemancingan. Ikan yang tersedia yaitu ikan lele dengan ukuran cukup besar. Jam operasional pemancingan ini yaitu 24 jam non-stop sehingga membuka peluang yang besar bagi pemancing agar dapat menghabiskan waktunya.

\section{Rasionalisasi konsumen yang berkunjung di Usaha Pemancingan}

Pada masa pandemi covid-19 tentu banyak masyarakat yang merasa bosan dengan rutinitas yang monoton, apalagi harus menjauhi keramaian. Memancing merupakan salah satu kegiatan yang dapat menghilangkan kejenuhan. Oleh karena itu minat memancing pada masa pandemi ini meningkat. Di desa Kalijambe Kidul sudah terdapat 3 tempat pemancingan dengan jarak yang tidak berjauhan.

Banyak warga yang berkunjung di Usahapemancingan dikarenakan beberapa hal yaitu:

a. Lokasi yang strategis

Usaha pemancingan berada di jalan raya sehingga memudahkan untuk menarik konsumen. Sedangkan tempat pemancingan lainnya bukan berada di raya. Oleh karena itu pemilihan lokasi sudah tepat.

b. Harga murah

Penetapan tarif memancing per-jam relatif murah dengan disediakan berbagai pilihan paket agar lebih hemat.

c. Mengurangi rasa bosan

Selama pandemi berlangsung tingkat stres dapat meningkat karena kejenuhan. Oleh karena itu manusia perlu merefresh kembali dengan berbagai cara, salah satunya dapat dilakukan dengan memancing.

d. Lokasi dekat

Dengan adanya pemberlakukan PSBB memberikan kebebasan memancinng namun hanya sebatas dalam daerah masing-masing. Oleh karena itu konsumen Usaha pemancingan mayoritas adalah warga kalijambe itu sendiri. Menurut Riski dalam wawancara pada tanggal 13 Juli menyebutkan 
bahwa "untuk mengurangi rasa jenuh, memancing merupakan alternatif kegiatan yang dapat dilakukan, apalagi dengan lokasi pemancingan yang dekat rumah”.

e. Diberhentikan kerja

Akibat pandemi covid-19 tidak jarang perUsahaan mengurangi jumlah karyawannya, sehingga banyak karyawan yang menganggur. Untuk mengisi waktu luang tersebut beberapa orang melakukan kegiatan memancing. Salah satunya dilakukan oleh Reza dalam wawancara pada tanggal 15 Juli 2020 menyebutkan bahwa "selama belum ada pekerjaan, saya sering memancing di Usaha pemancingan, saya sudah Usaha untuk mencari pekerjaan namun di era covid ini sulit sehingga saya butuh memancing untuk menenangkan diri”. Dalam wawancara yang sudah dilakukan penulis, banyak orang yang memancing karena kehilangan pekerjaan mereka.

f. Mengurangi penggunaan gadget

Sejalan dengan perkembangan zaman, kita dituntut agar dapat memanfaatkan teknologi dengan sebaik mungkin. Namun terlalu sering menggunakan gadget juga kurang baik bagi kesehatan tubuh. Oleh karena itu, memancing dapat mengurangi penggunaan gadget dan dapat merelaksasi tubuh.

\section{Profitabilitas bisnis Usaha pemancingan Tahun 2020}

Menurut (Muhammad Suryadi, 2019) Biaya produksi adalah total biaya tetap yang dijumlahkan dengan biaya variabel. Biaya produksi yaitu biaya-biaya yang digunakan mulai dari persiapan produksi sampai pada pemasaran. Biaya tetap (fixed cost) merupakan biaya yang besarnya tidak dipengaruhi oleh volume kegiatan Usaha, mulai dari produksi sampai pemasaran. Biaya tetap dalam penelitian ini meliputi nilai penyusutan alat, nilai sewa tanah, dan pajak.

Tabel 1. Biaya Tetap Usaha pemancingan

\begin{tabular}{ccc}
\hline No. & Jenis Biaya & Rupiah/Bulan \\
\hline 1 & Penyusutan alat & Rp. 146.000 \\
2 & Nilai Pajak & Rp. 10.000 \\
\hline & Jumlah & Rp.156.000
\end{tabular}

Sumber: Data diolah 2020.

Bisnis pemancingan mempunyai biaya tetap yakni biaya penyusutan alat sebesar Rp. 146.000, dan nilai pajak sebesar Rp. 10.000, Sehingga jumlah biaya tetap dalam satu bulan adalah Rp.156.000. Menurut Muhammad Suryadi (2019) biaya variabel merupakan biaya yang dikeluarkan selama proses produksi 
berlangsung sehingga jumlahnya dipengaruhi oleh banyak sedikitnya produksi. Biaya variabel dalam penelitian ini meliputi pembelian ikan siap pancing, umpan pancing, listrik, gaji karyawan.

Tabel 2. Biaya Variabel Usaha pemancingan

\begin{tabular}{|c|c|c|c|c|}
\hline No. & Jenis Biaya & $\begin{array}{l}\text { Jumlah } \\
\text { (satuan) }\end{array}$ & Harga (Rp) & Total Biaya \\
\hline 1 & $\begin{array}{l}\text { Pembelian } \\
\text { ikan siap } \\
\text { pancing }\end{array}$ & $600 \mathrm{~kg}$ & Rp. 20.000 & Rp. 12.000 .000 \\
\hline 2 & $\begin{array}{l}\text { Umpan } \\
\text { pancing } \\
\text { (cacing) }\end{array}$ & $25 \mathrm{~kg}$ & Rp. 65.000 & Rp. 1.625 .000 \\
\hline 3 & Listrik & & & Rp. 100.000 \\
\hline 4 & Gaji & 6 & $\begin{array}{c}\text { Rp. } \\
1.000 .000\end{array}$ & Rp. 6.000 .000 \\
\hline & & & Jumlah & 19.725 .000 \\
\hline
\end{tabular}

Sumber: Data diolah 2020.

Biaya variabel pada bisnis Usaha pemancingan terdiri dari biaya pembelian ikan siap pancing sebanyak $600 \mathrm{~kg}$ dalam sebulan kurang lebih Rp. 12.000.000, umpan pancing Rp. 1.625.000, Biaya Listrik Rp. 100.000, dan Gaji Rp. 6.000.000. Sehinggga total biaya variabel pada bisnis Usaha pemancingan sebesar Rp. 19.725.000. Menurut Muhammad Suryadi (2019) total biaya produksi adalah seluruh biaya produksi yang telah dikeluarkan yaitu penjumlahan antara biaya tetap dengan biaya variabel.

Tabel 3. Biaya Produksi Usaha pemancingan

\begin{tabular}{ccc}
\hline No. & Jenis Biaya & Nilai (Rp/Bulan) \\
\hline 1 & Biaya Tetap & Rp.156.000 \\
2 & Biaya Variabel & Rp. 19.725 .000 \\
\hline & Jumlah & Rp. 19.881 .000 \\
\hline
\end{tabular}

Sumber: Data diolah 2020. 
Berdasarkan tabel diatas, dapat diketahui bahwa biaya yang harus dikeluarkan untuk memproduksi setiap bulannya sebesar Rp. 19.881.000 yang terdiri dari biaya tetap sebesar Rp.156.000 yang dijumlahkan dengan biaya variabel sebesar Rp. 19.725.000. Menurut Muhammad Suryadi (2019) penerimaan adalah total uang diterima yang diperoleh dari hasil Usaha yang dijalankan. Rincian penerimaan hasil Usaha akan dijelaskan sebagai berikut:

Tabel 4. Penerimaan Usaha pemancingan

\begin{tabular}{|c|c|c|c|c|}
\hline No. & Jenis Biaya & satuan & Harga (Rp) & Total Biaya \\
\hline & Tiket & & & Rp. 37.325 .000 \\
\hline \multirow[t]{2}{*}{1} & Masuk & $\begin{array}{l}7.465 \\
\text { jam }\end{array}$ & Rp. 5.000 & \\
\hline & Umpan & & Rp. 70.000 & Rp. 1.750 .000 \\
\hline \multirow[t]{2}{*}{2} & $\begin{array}{l}\text { pancing } \\
\text { (cacing) }\end{array}$ & $25 \mathrm{~kg}$ & & \\
\hline & & & Jumlah & 39.075 .000 \\
\hline
\end{tabular}

Sumber: Data diolah 2020.

Bisnis Pemancingan ikan milik bu Lisa Susanti dalam satu bulan menghasilkan omset / penerimaan sebesar Rp. 39.075.000 yang diterima Usaha pemancingan ini. Menurut Muhammad Suryadi (2019) profitabilitas atau keuntungan merupakan selisih antara total penerimaan (TR) dengan total biaya produksi (TC). Untuk menghitung profitabilitas bisnis Usaha pemancingan maka dapat menggunakan rumus sebagai berikut:

$$
\pi=\mathrm{TR}-\mathrm{TC}
$$

Keterangan:

$\mathrm{TR}=$ total penerimaan (harga tiket $\mathrm{x}$ satuan terjual)

$\mathrm{TC}=$ total biaya (biaya tetap + biaya variabel)

$\pi=\mathrm{TR}-\mathrm{TC}$

$=$ Rp. $39.075 .000-$ Rp. 19.881 .000

$=$ Rp. 19.194.000/ bulan

Keuntungan bersih yang diperoleh USAHA pemancingan dalam satu bulan yaitu bulan juni 2020 sebesar Rp. 19.194.000. 


\section{Kesimpulan}

Coronaviruses merupakan virus yang menginfeksi saluran pernafasan. Infeksi dari virus ini disebut dengan covid-19. Dari serangan virus tersebut, tidak sedikit orang yang meninggal disebabkan covid-19. Penyebaran virus ini sangat pesat sehingga beberapa sektor di Indonesia mengalami keguncangan. Dimana sektor-sektor tersebut merupakan penopang dari penerimaan pajak terbanyak di Indonesia. Dengan adanya pembatasan sosial berskala besar mengakibatkan UMKM mengalami penurunan omset yang sangat drastis. Mulai dari bisnis fashion, elektronik, peralatan rumah tangga, taman bermain anak-anak, hingga bisnis pemancingan. Beberapa Usaha pemancingan mengalami kerugian material yang cukup besar akibat pandemi ini. Namun berbeda dengan Usaha pemancingan yang justru mengalami peningkatan omset pada era pandemi covid-19. Banyak konsumen Usaha pemancingan yang berkunjung dikarenakan beberapa hal yaitu: lokasi yang strategis, harga murah, mengurangi rasa bosan, lokasi dekat, diberhentikan kerja, dan mengurangi penggunaan gadget. Omset yang dihasilkan oleh Usaha pemancingan pada bulan juni 2020 yaitu sebesar Rp. 37.325.000 dengan total keuntungan sebesar Rp. 17.600.000. 


\section{References}

Budastra, I. K. (2020). Dampak Sosial Ekonomi Covid-19 dan Program Potensial untuk Penanganannya: Studi Kasus di Kabupaten Lombok Barat. Jurnal Agrimansion, 21(1), 48-57.

Hanoatubun, S. (2020). Dampak Covid-19 terhadap Prekonomian Indonesia. EduPsyCouns: Journal of Education, Psychology and Counseling, 2 (1), 146-153.

Kurnia, F. (2020). Kegiatan Memancing Juga Terimbas Pandemi Covid-19. Retreived Juli 14, 2020, from gatra.com website: https://www.gatra.com/detail/news/481114/gaya-hidup/kegiatan-memancingjuga-terimbas-pandemi-covid-19

Kurniawan Syah, P. (2020). Cegah covid-19, Wisata Mancing di Muaragembong Bekasi ditutup. Retreived Juli 16, 2020, from antaranews.com website: https://www.antaranews.com/berita/1390214/cegahcovid-19-wisata-mancing-di-muaragembong-bekasi-ditutup

Rezy, F. (2018). Pancing Keuntungan Dari Bisnis Kolam Pemancingan. Retrieved Juli 30, 2020, from economy.okezone.com website: https://economy.okezone.com/read/2018/03/16/320/1874016/pancing-keuntungan-dari-bisniskolam-pemancingan

S Adyna, A. (2020). Industri Tetap Tumbuh Saat Pandemi. Retrieved Juli 30, 2020, from ekbis.sindonews.com website: https://ekbis.sindonews.com/read/52210/33/empat-industri-ini-tetap-bertumbuh-saatpandemi-covid-19-1590793521

Sailendra, H. (2020). Resto Pemancingan dan Wahana Permainan Anak Duren Jati Darupono Siap dibuka. Retreived Juli 16, 2020, from halosemarang.id website: https://halosemarang.id/resto-pemancingandan-wahana-permainan-anak-duren-jati-darupono-siap-dibuka

Suryadi, M. (2019). Analisis Pendapatan Usaha Rekreasi Pemancingan Ikan “Denis” Di Desa Kotapulu Kecamatan Dolo Kabupaten Sigi. Agrotekbis: E-Jurnal Ilmu Pertanian, 7(2), 274-279.

Thaha, A. F. (2020). Dampak Covid-19 Terhadap UMKM Di Indonesia. BRAND Jurnal Ilmiah Manajemen Pemasaran, 2(1), 147-153. 